\title{
A TIME FOR PEACE
}

\author{
Future plans.
}

\section{BY S. R. ALGERNON}

CC 7 hy do you deserve a place here, Oscar?" asked the director, as he eyed Oscar from across a
rdy oak desk. A painting of Speer's Volkerbundhalle and the Berlin skyline dominated the wall behind him.

Oscar looked down at his fidgety knees to avoid the director's glare. He had not prepared himself for silence. He had imagined the Institute as a place where the air danced with the roar of engines and the crackle of a welder's torch, or at least the clack of chalk against slate.

Nobody deserved a place at the Institute, thought Oscar. The Institute plucked them from the world like the tip of a tornado and hurled them into the maelstrom of history. Fermi put his studies on hold for three years and emerged in 1924 with a complete understanding of nuclear fission. Alan Turing took a summer off from Sherborne and crossed the pond to New Jersey. By 1935, the first business computers rolled off the production line.

Ten seconds passed. The director's office was quiet, except for the steady sweeping of a broom and the snip of hedge trimmers outside the window.

Oscar swallowed and took a breath.

"It all comes down to quantum tunnelling. We've always assumed that time travel involved moving through space-time in accordance with Dr Einstein's theories, but if Dr Born is right..."

"It is not a question of if," said the director. He reached into his desk and pulled out a photograph. "This was our founding conference, after the Great War. Look in the third row."

An inscription in the upper left corner read POTSDAM, 1919. Just below it, between Heisenberg and Rutherford, Oscar saw a bearded version of himself.

"I was there?"

"You and your boxcar full of journals and blueprints. You convinced Heisenberg, and he convinced the rest. Together, you drew up the plans for the twentieth century."

"So ... I am, or will be, the first time traveller?"

"The Oscar that appeared in Potsdam 50 years ago is a matter of historical record. I want to know who you are. Are you - the you that sits in my office - necessary to move history onto its present path?"

"The grandfather paradox," said Oscar, with a chuckle. "It's not a problem. Moving through time implies velocity and causation. Quantum tunnelling through time is different. The time traveller simply appears ex nihilo from the quantum foam. The traveller's emergence on the scene is, to be sure, an improbable event, but it has no destiny and it owes nothing to the future."

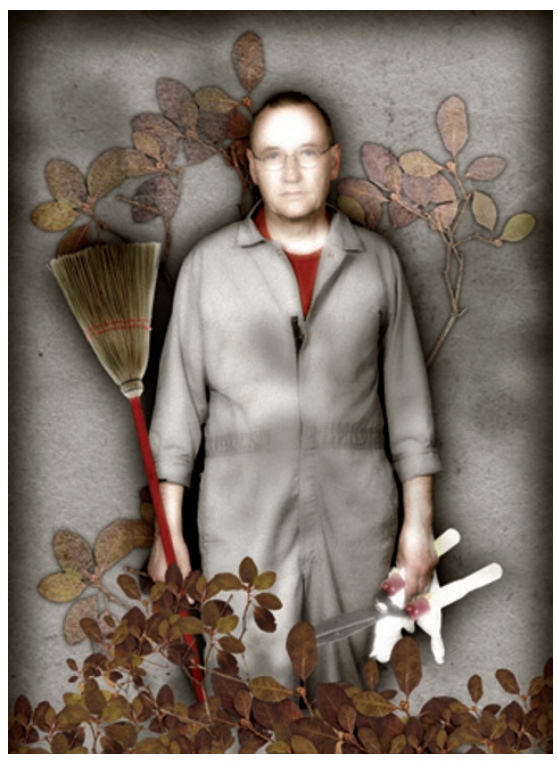

"So, you do not have a destiny?"

"Maybe not," said Oscar, "but I hope you'll agree that I still have potential. I will find a way to unwind time to an earlier state. The history books tell us that Brown and Reitsch walked on the Moon in 1947. What if it were Lindbergh in 1927 or da Vinci in 1497?"

The director stroked his chin.

"And what about all the people in this timeline? Will they agree to wink out of existence to create your perfect world?"

"Once the timeline is unwound, everyone here will be unrealized potential. They won't get a choice. After all, nobody gets to vote on what time it is."

"But you do. Or, you will. Doesn't that make you responsible for the people you leave behind?"

"What can I do for them? They won't even exist. Am I obliged to consider every potential human life, not just every embryo but every possible union of sperm and egg?" $\rightarrow$ NATURE.COM

Follow Futures: y @NatureFutures $f$ go.nature.com/mtoodm
"Perhaps not," said the director. "I think we have a place for you after all. Our programme will be intensive. Have you explained to your friends and relatives that you will be quite busy for some time and should not be disturbed?"

"Of course."

"Good," said the director. He stood up and offered his hand. "Welcome. I will show you to your room."

The room, at the other end of the quad, was sparse and tidy, like a monk's cell. A grey jumpsuit lay neatly on the bed. At first, the sight startled him. Did Turing have to sweep the paths when he was here? Did Fermi have to trim the hedges?

Oscar stepped tentatively up to the window. Outside, a man sat with his back to Oscar, facing a watercolour of a Bavarian castle against the backdrop of an idyllic Wagnerian landscape. Oscar tried to lean out the window to get the artist's attention, but it opened only a few centimetres, not enough for him to squeeze his head through.

"Hallo, nachbar," said Oscar, eager to try out a little German.

The artist slowly turned, without lowering his brush.

"Ja," said the painter, without inflection, looking vaguely towards Oscar's window. "Hallo, nachbar." His head drifted back towards the canvas, and he added a few brushstrokes.

Oscar took a step back, unimpressed. He had expected to meet the next Einstein or Heisenberg, not some undersized Charlie Chaplin. He turned back to the director.

"There must be some mistake," said Oscar. "I'm no painter or gardener. What about my future? What about history?"

The old man's smile drew the skin taut over his face.

"You may owe this world no debt, but we have our own obligations. I'm sure you'll understand if we prefer to leave the timeline as it is."

Oscar stepped towards the door, but the director slammed it shut. On the other side, a deadbolt slid firmly into place.

Oscar staggered backwards to the bed, hearing the sound of his own quickened heartbeat and the even cadence of pruning shears. After each slice, branches struck the pavement and waited for the broom to sweep them away.

\section{S. R. Algernon studied fiction writing} and biology, among other things, at the University of North Carolina at Chapel Hill. He currently lives in Singapore. 